WIDYA BIOLOGI

\title{
UJI CEMARAN COLIFORM DAN Escherichia coli PADA AIR SUMUR GALI DISEKITAR TEMPAT PEMOTONGAN TERNAK BANJAR KEDEN DESA KETEWEL KECAMATAN SUKAWATI KABUPATEN GIANYAR
}

\section{(COLIFORM AND ESCHERICHIA COLI CONTAMINATION TEST IN DUG WELL WATER AROUND WASTE DUMPS OF CATTLE SLAUGHTERING AT BANJAR KEDEN, KETEWEL VILLAGE SUKAWATI SUB-DISCTRIC, GIANYAR DISTRIC)}

\author{
Sudiartawan I P. ${ }^{1}$, Arya Bawa I P. ${ }^{2}$, Juliasih N. K. ${ }^{1}$ \\ ${ }^{1}$ Fakultas Fakultas Teknologi Informasi dan Sains Universitas Hindu Indonesia \\ ${ }^{2}$ Program Studi Biologi FTIS Universitas Hingu Indonesia \\ Email: sudikpt12@yahoo.com
}

\begin{abstract}
One of the sources of water to fulfill human needs is wells. This research aims to determine Coliform and E. coli in the water wells around TPT Banjar Keden, Ketewel village, Sukawati District, Gianyar Regency. Research conducted in July until September 2019. Sampling water wells using stratified systematic unaligned sampling method.The distance and the sampling place of the water wells from the sample point one to the other point of the sample are not in a one straight line. The results of the research analyzed by descriptive comparative, referring to the regulation of the Minister of Health of Republic of Indonesia No. 32 of 2017 on the standard quality for environmental health and water health requirements for hygiene purposes sanitation, swimming Pool, Solus Per Aqua, and public bath and Bali Governor regulation No. 16 of 2016 on environmental quality standards and raw criteria for environmental damage. The results of the study for Coliform bacteria contamination showed that from 10 (ten) research samples, namely 3 (three) samples whose values had exceeded the quality standard of the Minister of Health's Regulation of the Republic of Indonesia No. 32 of 2017. Based on the Bali Governor's Regulation 16 of 2016, out of 10 (ten) the research sample shows that all are still below the environmental quality standard. The results of the study for E. coli bacteria contamination for 10 (ten) study samples showed results of 0/100 $\mathrm{ml}$ and were still below the quality standard determined by the Republic of Indonesia Health Regulation No 32 of 2017 and the Governor of Bali Regulation No.16 of 2016.
\end{abstract}

Keyword: Livestock waste, Wells, Coliform Bacteria and E. coli.

\section{ABSTRAK}

Salah satu sumber air untuk memenuhi kebutuhan manusia adalah sumur gali. Penelitian ini bertujuan untuk mengetahui cemaran Coliform dan E.coli pada air sumur gali disekitar Tempat Pemotongan Ternak Banjar Keden, Desa Ketewel, Kecamatan Sukawati, Kabupaten Gianyar. Penelitian dilakukan pada bulan Juli sampai dengan bulan September 2019. Pengambilan sampel air sumur gali menggunakan metode stratified systematic unligned sampling, yaitu jarak dan 


\section{WIDYA BIOLOGI}

tempat pengambilan sampel air sumur gali dari stasiun pegambilan sampel satu ke titik sampel yang lain tidak dalam bentuk garis lurus. Data hasil penelitian dianalisis secara deskriptif komparatif, mengacu pada Peraturan Menteri Kesehatan Republik Indonesia Nomor 32 Tahun 2017 tentang Standar Baku Mutu Kesehatan Lingkungan dan Persyaratan Kesehatan Air Untuk Keperluan Higiene Sanitasi, Kolam Renang, Solus Per Aqua, dan Pemandian Umum dan Peraturan Gubernur Bali No. 16 Tahun 2016 tentang Baku Mutu Lingkungan Hidup dan Kriteria Baku Kerusakan Lingkungan Hidup. Hasil penelitian untuk cemaran bakteri Coliform menunjukan bahwa dari 10 (sepuluh) sampel penelitian, terdapat 3 (tiga) sampel yang nilainya telah melampaui nilai baku mutu Peraturan Menteri Kesehatan Republik Indonesia Nomor 32 Tahun 2017. Sedangkan berdasarkan Peraturan Gubernur Bali No.16 Tahun 2016, dari 10 (sepuluh) sampel penelitian menunjukan semua masih berada dibawah baku mutu lingkungan. Hasil penelitian untuk cemaran bakteri E. coli untuk 10 (sepuluh) sampel penelitian menunjukkan hasil 0/100 ml dan masih dibawah nilai baku mutu yang ditetapkan berdasarkan Peraturan Kesehatan Republik Indonesia Nomor 32 Tahun 2017 dan Peraturan Gubernur Bali No.16 Tahun 2016.

Kata kunci : Limbah potong ternak, sumur gali, bakteri Coliform dan E. Coli

\section{PENDAHULUAN}

Air merupakan sumber kehidupan bagi Manusia. Dalam berbagai aktifitas khususnya untuk mandi, cuci dan kakus. Manusia tidak bisa hidup tanpa air akan tetapi manusia dapat hidup berminggu-minggu tanpa makanan sehingga air sangat penting bagi keberlangsungan kehidupan manusia. Tubuh manusia terdiri dari 50-60\% air, sehingga memegang peranan penting dalam kinerja organ-organ tubuh (Kusnaedi, 2004).

Manusia dalam memenuhi derajat kesehatan membutuhkan air yang bersih. Menurut Untung (2004) Air bersih adalah air yang jernih, tidak berwarna, tawar dan tidak berbau.
Melalui penyediaan air bersih dan sebagai pemenuhan kebutuhan seharihari, masyarakat melakukan suatu usaha dengan swadaya dana masyarakat sendiri yaitu dengan membuat sumur gali atau air tanah.

Air sumur gali adalah air permukaan tanah atau air tanah dangkal, umumnya kedalaman sampai $100 \mathrm{~m}$. Pembuatan sumur gali harus memperhatikan lokasi bebas dari pencemaran, agar air sumur tidak tercemar oleh bakteri-bakteri yang berbahaya.

Indikator kualitas air secara mikrobiologis salah satunya ditentukan oleh keberadaan bakteri Escherichia coli. Kualitas mikrobiologi untuk air 


\section{WIDYA BIOLOGI}

bersih wajib memenuhi persyaratan berdasarkan Peraturan Menteri Kesehatan Republik Indonesa No. 32 Tahun 2017 dan Peraturan Gubernur Bali No. 16 Tahun 2016 yaitu Total coliform kadar maksimum 50CFU/100ml dan Escherichia coli 0/100ml.

Desa Ketewel berada di Kecamatan Sukawati, Kabupaten Gianyar. Berdasarkan data dari Badan Pusat Statistik (BPS) Kabupaten Gianyar tahun 2018, meunjukkan desa ini terdata sebagai daerah dengan populasi ternak paling banyak di Kecamatan Sukawati,

Masyarakat di Desa Keden masih banyak mengkonsumsi air sumur gali sebagai bahan baku air minum, khusunya di Banjar Keden. Berdasarkan hasil observasi awal di lokasi penelitian air sumur gali yang jaraknya berdekatan dengan TPT (kurang dari 11 meter) sebagian besar terdapat di Banjar Keden Desa Ketewel, Kecamatan Sukawati, Kabupaten Gianyar. Menurut Waluyo (2009) jarak sumur gali minimal meter dari sumber pencemar, dengan demikian sebagian besar sumur gali yang terdapat di Banjar Keden dapat tercemar oleh limbah Tempat Pemotongan Ternak (TPT).

Berdasarkan uraian di atas, perlu dilakukan penelitian tentang Uji Cemaran Coliform dan Escherichia coli pada Air Sumur Gali di Sekitar Tempat Pemotongan Ternak di Banjar Keden, Desa Ketewel, Kabupaten Gianyar.

\section{BAHAN DAN METODE}

Penelitian ini merupakan penelitian observasional dilakukan melalui pendekatan deskriptif komparatif dengan cara membandingkan nilai MPN Coliform dan Escherichia coli dengan mengacu pada Permenkes RI No. 32 Tahun 2017 dan Pergub. Bali No. 16 Tahun 2016.

Penelitian ini dilakukan pada sumur gali penduduk disekitar tempat pemotongan ternak di Banjar Keden, Desa Ketewel, Kecamatan Sukawati, Kabupaten Gianyar, sedangkan untuk analisis sampel penelitian dilakukan di Laboratorium Bina Medika Denpasar.

\section{HASIL PEMBAHASAN}

Hasil

Hasil penelitian menujukkan bahwa dari 10 (sepuluh) sampel air sumur gali yang dianalisis ternyata terdapat 3 sampel (30\%) dikategorikan 


\section{WIDYA BIOLOGI}

tidak memenuhi syarat baku mutu lingkungan dan 7 sampel $(70 \%)$ dikategorikan memenuhi syarat baku mutu lingkungan menurut Peraturan Menteri Kesehatan Republik Indonesia No. 32 Tahun 2017 yang diperuntukkan untuk air bersih. Sementara jika dibandingkan dengan nilai baku mutu dari Peraturan Gubernur Bali No 16 Tahun 2016, hasil total coliform untuk 10 (sepuluh) sampel air sumur gali yang diteliti dikategorikan masih memenuhi syarat baku mutu lingkungan (Tabel 1).

Tabel 1 Hasil pemeriksaan MPN Coliform Air Sumur Gali di Banjar Keden

menunjukkan dari 10 (sepuluh) sampel penelitian yang diteliti tidak ditemukan bakteri E.coli. Hasil pemeriksaan E.coli air sumur gali di Banjar Keden, Desa Sukawati tercantum pada rata-rata-rata 0/100 ml (Tabel 2).

Tabel 2. Hasil pemeriksaan MPN E.coli Air Sumur Gali di Banjar Keden

\begin{tabular}{ccccc}
\hline & & Hasil & \multicolumn{2}{c}{ Baku Mutu MPN } \\
& Lokasi & pemeriksaan & \multicolumn{2}{c}{ E.coli } \\
\cline { 4 - 5 } No & Pengambilan & MPN E.colil & Permenkes & Pergub. \\
& Sampel & $100 \mathrm{ml}$ & No.32 TH & Bali \\
& & & 2017 & No.16 TH \\
& & & & 2016 \\
\hline 1 & 1 & 0 & $0 / 100$ & $1000 / 100$ \\
& & & $\mathrm{~mL}$ & $\mathrm{~mL}$ \\
2 & 2 & 0 & $0 / 100$ & $1000 / 100$ \\
& & & $\mathrm{~mL}$ & $\mathrm{~mL}$ \\
3 & 3 & 0 & $0 / 100$ & $1000 / 100$
\end{tabular}

$\begin{array}{lllll}3 & 3 & 0 & 0 / 100 & 1000 / 100\end{array}$

\begin{tabular}{|c|c|c|c|c|c|c|c|c|}
\hline \multirow[b]{2}{*}{ No } & \multirow[b]{2}{*}{$\begin{array}{c}\text { Lokasi } \\
\text { Pengambilan }\end{array}$} & \multirow{2}{*}{$\begin{array}{c}\text { Hasil } \\
\text { Pemeriksaan } \\
\text { MPN } \\
\text { Coliform/ } \\
100 \mathrm{ml} \\
\end{array}$} & \multicolumn{2}{|c|}{$\begin{array}{l}\text { Baku Mutu MPN } \\
\text { Coliform }\end{array}$} & 4 & 0 & $\begin{array}{c}\mathrm{mL} \\
0 / 100 \\
\mathrm{~mL}\end{array}$ & $\begin{array}{c}\mathrm{mL} \\
1000 / 100 \\
\mathrm{~mL}\end{array}$ \\
\hline & & & $\begin{array}{c}\text { Permenkes } \\
\text { No.32 TH } \\
2017\end{array}$ & $\begin{array}{c}\text { Pergub 5 } \\
\text { No.16 TH } \\
2016\end{array}$ & 5 & 0 & $\begin{array}{c}0 / 100 \\
\mathrm{~mL}\end{array}$ & $\begin{array}{c}1000 / 100 \\
\mathrm{~mL}\end{array}$ \\
\hline 1 & 1 & $64^{*}$ & $50 / 100 \mathrm{~mL}$ & $\begin{array}{c}5000 / 100 \\
\mathrm{~mL}\end{array}$ & 6 & 0 & $\begin{array}{c}0 / 100 \\
\mathrm{~mL}\end{array}$ & $\begin{array}{c}1000 / 100 \\
\mathrm{~mL}\end{array}$ \\
\hline 2 & 2 & 39 & $50 / 100 \mathrm{~mL}$ & $\begin{array}{c}5000 / 1007 \\
\mathrm{~mL}\end{array}$ & 7 & 0 & $\begin{array}{c}0 / 100 \\
\mathrm{~mL}\end{array}$ & $\begin{array}{c}1000 / 100 \\
\mathrm{~mL}\end{array}$ \\
\hline 3 & 3 & 28 & $50 / 100 \mathrm{~mL}$ & $\begin{array}{c}5000 / 100 \\
\mathrm{~mL}\end{array}$ & 8 & 0 & $\begin{array}{c}\mathrm{mL} \\
0 / 100\end{array}$ & $1000 / 100$ \\
\hline 4 & 4 & 43 & $50 / 100 \mathrm{~mL}$ & $5000 / 100$ & & & $\mathrm{~mL}$ & $\mathrm{~mL}$ \\
\hline 5 & 5 & 43 & $50 / 100 \mathrm{~mL}$ & $\begin{array}{c}\mathrm{mL} 9 \\
5000 / 100 \\
\mathrm{~mL}\end{array}$ & 9 & 0 & $\begin{array}{c}0 / 100 \\
\mathrm{~mL}\end{array}$ & $\begin{array}{c}1000 / 100 \\
\mathrm{~mL}\end{array}$ \\
\hline 6 & 6 & $75^{*}$ & $50 / 100 \mathrm{~mL}$ & $\begin{array}{l}5000 / 10 \emptyset 0 \\
\mathrm{~mL}\end{array}$ & 10 & 0 & $\begin{array}{c}0 / 100 \\
\mathrm{~mL}\end{array}$ & $\begin{array}{c}1000 / 100 \\
\mathrm{~mL}\end{array}$ \\
\hline 7 & 7 & 39 & $50 / 100 \mathrm{~mL}$ & $\begin{array}{c}5000 / 100 \\
\mathrm{~mL}\end{array}$ & & & & \\
\hline
\end{tabular}

$\begin{array}{ccccc}8 & 8 & 43 & 50 / 100 \mathrm{~mL} & \begin{array}{c}5000 / 100 \\ \mathrm{~mL}\end{array} \\ 9 & 9 & 75^{*} & 50 / 100 \mathrm{~mL} & \begin{array}{c}5000 / 100 \\ \mathrm{~mL}\end{array}\end{array}$ Pembahasan

$\begin{array}{lllll}10 & 10 & 39 & 50 / 100 \mathrm{~mL} & 5000 / 100\end{array}$
$\mathrm{mL}$

Banjar Keden merupakan salah satu banjar yang terdapat di Desa Ketewel, dimana sebagian besar masyarakatnya Hasil penelitian pada air sumur masih memanfaatkan air sumur gali gali untuk parameter E. coli, sebagai sumber air bersih sedangkan untuk air minum menggunakan air isi 


\section{WIDYA BIOLOGI}

ulang. Dari hasil penelitian, masyarakat di lokasi Banjar Keden untuk memenuhi kebutuhan air bersih seperti untuk mandi, mencuci dan lainnya yang berhubungan dengan kesehatan menggunakan air sumur gali. Berdasarkan hasil penelitian menunjukkan bahwa MPN Coliform dari 10 sampel air sumur gali yang diteliti ternyata ada 3 (tiga) sampel air (30\%) yang nilai MPN Coliformnya telah melampui baku mutu lingkungan berdasarkan Peraturan Menteri Kesehatan Republik Indonesia No. 32 Tahun 2017 yaitu sampel 1 (satu), 6 (enam), dan 9 (sembilan) dengan nilai MPN Coliform secara berturut turut sebesar : 64/100 ml, 75/100 $\mathrm{ml}$ dan 75/100 ml. Sedangkan berdasarkan Peraturan Gubernur Bali No 16 Tahun 2016 nilai MPN Coliform untuk 10 (sepuluh) sampel air sumur gali masih memenuhi baku mutu lingkungan sebagai air minum Kelas II.

Ditemukanya bakteri Coliform pada air sumur gali di Banjar Keden dengan jumlah diatas standar baku mutu lingkungan pada sampel 1 (satu), 6 (enam), dan 9 (sembilan) disebabkan karena sumur gali pada ketiga stasiun tersebut letaknya paling dekat dengan septictank ( \pm 11 meter ) selain itu lokasi sumur gali tersebut juga dekat dengan saluran limbah pemotongan ternak (TPT) dibandingkan dengan ketujuh stasiun lainya, sehigga rembesan air limbah dari pemotongan ternak bisa masuk kedalam sumur gali. Adanya septictank menurut Susanta (2008) merupakan tempat pembuangan akhir untuk air besar dan kloset, pemilihan tempat dan model septictank sangat berpengaruh terhadap kesehatan, ini disebabkan jarak rembesan septictank dan sumur minimal 11 meter. Selain itu, persyaratan septic tank dan sumur gali yang baik memiliki jarak 11 meter (Depkes RI, 1994). Limbah septictank sangat mempengaruhi pencemaran terhadap sumur gali (Nazar, 2010).

Tingginya nilai bakteri coliform pada ketiga stasiun tersebut di mungkinkan oleh adanyanya kontruksi sumur yang masih sederhana, tidak tertutup, lantai sumur sudah rusak (retak-retak), dan tergenang air limbah domestik (air cucian prabotan rumah tangga dan pakaian), pengambilan air dilakukan dengan cara menimba dengan ember, dimana ember tersebut tidak dijaga kebersihannya. Hal ini sesuai dengan pendapat yang dikemukakan Chandra 


\section{WIDYA BIOLOGI}

(2006) diantaranya : Lokasi sumur gali harus jauh dari sumber pencemar terdekat yaitu berkisar antara 10-15 m dari sumber pencemar (septictank, tempat pembuangan sampah), lantai sumur harus kedap air minimal 1 meter dari bibir sumur, tidak retak, mudah dibersihkan dan tidak tergenang air; pengambilan air sebaiknya menggunakan pompa isap untuk mencegah pencemaran dari luar, tetapi bila harus memakai timba maka setiap selesai dipergunakan timba air diletakkan dengan baik agar terjaga kebersihannya; tutup sumur sebaiknya ditutup secara permanen bila proses mengambil airnya menggunakan mesin pompa untuk mencegah sumber pencemar masuk ke dalam sumur dan digunakan tutup buka pasang bila air di ambil dengan mengunakan ember mencegah kotoran masuk kedalam sumur

Berkaitan dengan hasil penelitian yang dilaporkan oleh Khomariyatika dan Pawenang (2011) tentang kualitas baktriologi air sumur gali yang dilaporkan dinyatakan bahwa kualitas bakteriologi air sumur gali di Dusun Glonggong, Desa Doplang, Kecamatan Jati, Kabupaten Blora berhubungan dengan letak timba dan jarak jamban. Selanjutnya penelitian yang dilakukan oleh Mangarey dkk (2014) di Desa Moyong, Kota Kecamatan, Modayang Barat menunjukan bahwa ada hubungan bermakna antara kontruksi sumur dengan jumlah coliform air sumur gali. Pencemaran lain yang menjadi penyebab tercemarnya sumur gali kemungkinan disebabkan oleh aktivitas penghuni rumah banyak menghasilkan limbah dan apabila tidak dikelola dengan benar akan mencemari air sumur. Kegiatan tersebut antara lain: mengelola sampah tidak benar seperti sampah yang tercecer di sekitar sumur, saluran air yang tidak memenuhi syarat seperti kontruksinya yang sudah retak sehingga memungkinkan rembesan air kotor ke sumur. Menurut Chandra (2006) jenis pencemar yang banyak meresap pada sumber air dapat berasal dari: sumber domestik (rumah tangga) dan sumber non domestik (peternakan dan perikanan). Setyawati (2007), juga menyatakan bahwa kandungan bakteri yang terdapat dalam air sumur dipengaruhi oleh konstruksi sumur, aktivitas domestik sekitar sumur, cara penggunaan sumur, dan pemeliharaan sumur. 


\section{WIDYA BIOLOGI}

Sementara itu, 7 (tujuh) sampel (70\%) air sumur gali lainya tidak tercemar coliform. Dikarenakan kontruksi sumur gali masih bagus, (tidak retak), penutup sumur sudah permanen yang terbuat dari beton, sudah menggunakan pompa isap, tidak ada genangan air limbah domestik disekitar sumur, jarak sumur dengan sumber pencemar (septic tank dan TPT) diatas 11 meter. Kondisi tersebut menyebabkan sumur tidak terkontaminasi bakteri coliform.

Hasil penelitian untuk parameter Escherichia coli pada 10 (sepuluh) stasiun penelitian menunjukan semua sampel (100\%) tidak teridentifikasi adanya pencemaran oleh bakteri Escherichia coli yaitu dengan nilai masing-masing 0/100 ml. Tidak adanya bakteri Escherichia coli pada air sumur gali dilokasi penelitian dimungkinkan oleh adanya septictank dan saluran limbah pemotongan ternak (TPT) yang dimiliki oleh warga tersebut berfungsi dengan baik dan jaraknya sudah memenuhi syarat pembuatan sumur, serta didukung oleh perilaku sehari-hari masyarakat yang cukup memahami cara hidup sehat antara lain semua anggota keluarga buang air besar di jamban, hewan peliharaan tidak berkeliaran bebas dihalaman rumah serta mencuci bersih tangan dengan sabun setelah buang air besar. Hal ini didukung juga oleh jenis tanah regusol coklat yaitu mendekati kondisi tanah liat, yang memiliki sifat permeabilitas rendah sehingga tidak mudah melewatkan air yang meresap ke dalam tanah. Hal ini didukung oleh persyaratan Depkes RI, (1994) menyatakan bahwa septictank dan sumur gali yang baik memiliki jarak lebih dari 11 meter. Berdasarkan penelitian Heriyani Hasnawai (2012) tentang analisis kualitas bakteriologi dan observasi analisis statistik menunjukkan bahwa ternyata aspek jarak sumur dengan sumber pencemar berpengaruh terhadap jumlah bakteri Escherichia coli pada air sumur gali.

\section{SIMPULAN}

Dari hasil penelitian dapat disimpulkan sebagai berikut : terdapat 3 sumur gali dari 10 sumur gali yang diteliti tercemar bakteri MPN Coliform berdasarkan Peraturan Menteri Kesehatan Republik Indonesia No. 32 Tahun 2017. Sedangkan untuk parameter E. coli pada 10 sampel air sumur gali yang diteliti masih dibawah nilai baku mutu yang ditetapkan berdasarkan Peraturan Kesehatan 


\section{WIDYA BIOLOGI}

Republik Indonesia Nomor 32 Tahun 2017 dan Peraturan Gubernur Bali No.16 Tahun 2016.

\section{SARAN}

Untuk mencegah terjadinya pencemaran air sumur gali secara bakteriologis dapat dilakukan dengan memperhatikan jarak sumur dengan sumber pencemar dan melengkapi sumur dengan penutup sehingga potensi pencemaran dapat diminimalkan.

\section{DAFTAR PUSTAKA}

Badley. 1974. Waste Water Treatment. Penerbit USA Prentice. Hall Inc.

Badan Pusat Statistik. 2018. Kecamatan Sukawati Dalam Angka 2018. Badan Pusat Statistik Kabupaten Gianyar. Gianyar.

Bambang, A.G., Fatimawali, dan N. Kojong. 2014. Analisis Cemaran Bakteri Coliform dan Identifikasi Escherichia coli pada Air Isi Ulang dari Depot di Kota Manado. Jurnal Ilmiah Farmasi. Universitas Sam Ratulangi, Manado,

Chandra, B. 2007. Pengantar Kesehatan Lingkungan. Puspa Swara. Jakarta

Dwidjoseputro, D. 1987. Dasar-Dasar Mikrobiologi.Djambatan. Malang.

Depkes, RI. 1985. Farmakope Indonesia. Jakarta: Ditjen POM. Depkes, RI. 1995.

Farmakope Indonesia. Edisi IV. Jakarta
Depkes RI, 1991. Petunjuk Pemeriksaan Bakteriologis Air. Jakarta : Depkes. Pusat Laboratorium Kesehatan

Depkes RI.1994. Penyehatan Air dalam Progarm Penyedian dan Pengelolaia air bersih. Jakarta : direktorat jendral ppm dan ppl depertemant kesehatan RI.

Effendi, H. 2003. Telaah Kualitas Air Bagi Pengelolaan Sumber Daya dan Lingkungan Perairan. PT. Kanisius. Yogyakarta.

Fardiaz, S. 1993. Analisis Mikrobiologi Pangan. PAU. IPB

Heriyani, H.2012.Pengaruh Konstruksi Sumur Terhadap Kandungan Bakteri Eschercia coli Pada Air Sumur Gali Di Desa Dopalak Kecamatan Paleleh Kabupaten Buol. Skripsi, jurusan Kesehatan masyarakat, Fakultas Ilmu-Ilmu Kesehatan dan Keolahragaan, Universitas Negeri Gorontalo

Kelly, F. 2005. Microbiology, Edition 2. Appleeton Century Crofts, New York.

KESMAS.2016. Syarat Jarak Aman antara Septictank dengan Sumur Gali dan Faktor yang Mempengaruhinya. (Internet) Tersedia di: http://www.indonesianpublichealth.com/jarak-septictank/.

Diakses pada 28 Maret 2019.

Kodoatie J. Robert, dan Sjarief, Roestam. 2008. Pengelolaan Sumber Daya Air Terpadu (Revisi). ANDI.Yogyakarta 


\section{WIDYA BIOLOGI}

Khomariyatika.T dan E.T.Parwenang. 2011. Kualitas Bakteriologis air sumur gali. At. Avalible fromhttp://journal.unnes.ac.id/inde x.php/kemas. Diaksek pada tanggal 15 September 2019

Kusnaedi. 2004. Mengolah Air Gambut dan Air Kotor untuk Air Minum, Puspa Swara. Jakarta

Mangarey, F. B., R. C. Sondakh dan P. A. T. Kawatu. 2014. Hubungan Antara Konstruksi Sumur Gali dan Jarak Terhadap Sumber Pencemar Dengan Kualitas Bakteriologis Air Sumur Gali di Desa Moyongkota Kecamatan Modayag Barat. Fakultas Kesehatan Masyarakat. Universitas Sam Ratulangi. Manado

Nazzar, H. 2010. Kebijakan pengendalian pencemaran sumber air bersih perumahan sederhana di kota pekan baru ( kasus dikecamatan tampan. Inperonmental, saince)

Notoatmodjo, 2003. Standar dan Persyaratan Sumur Sehat, Rineka Cipta. Jakarta

Pelczar, M.J. 2008. Dasar-dasar Mikrobiologi. UI Press.. Prasojo. Jakarta

Peraturan Menteri Kesehatan Republik Indonesia Nomor Permenkes No. 32 Tahun 2017 Tentang Standar Baku Mutu Kesehatan Lingkungan dan Persyaratan Kesehatan Air Untuk Keperluan Higiene Sanitasi, Kolam Renang, Solus per Aqua, dan Pemandian Umum.

Peraturan Gubernur Bali No. 16 Tahun 2016 Tentang Baku Mutu Lingkungan Hidup dan Kreteria
Baku Kerusakan Lingkungan Hidup.

Purwantoyo.2003, Kualitas Air Bersih Untuk Pemenuhan Kebutuhan Rumah Tangga Di Desa Pesarean Kecamatan Adiewerna Kabupaten Tegal.Skripsi.Universitas Negeri Semarang.

Robert J. Kodoatie, Roestam Sjarief, 2010. Tata Ruang Air.Penerbit ANDI Yogyakarta.

Sabarwati, Y. 1991. Uji Mikrobiologi Air Sumur Gali Di Tepi Anak Kali Surabaya, Di Daerah Gunungsari Dan Sekitarnya Kotamadya Surabaya. Skripsi. Universitas Airlangga. Jurusan Biologi Fakultas Matematika dan Ilmu Pengetahuan Alam Universitas Airlangga, Surabaya

Salim, E. 1986.Baku Mutu Lingkungan. KLH, Jakarta.

Siahaan, R, A. Indawan, D. Soedharma, dan L.B. Prasetyo. 2011. Kualitas air sungai Cisadane, Jawa Barat. Banten. Jurnal Ilmiah Sains.

Slamet, J. 2002. Kesehatan Lingkungan, Yogyakarta : Gajah Mada University Press.

Standar Nasional Indonesia (SNI) 032916-1992 tentang Spesifikasi Sumur Gali untuk Sumber Air Bersih.

Setiawati, A. 2007. Farmakologi Dan Terapi. Departemen Farmakologi dan Terapeutik FKUI, Jakarta

Suciastuti. 1996. Hubungan antara Tingkat Pendidikan dan Pendapatan dengan Penggunaan Air Sungai oleh Penduduk di Sekitar Sungai Kali Jajar Demak. 


\section{WIDYA BIOLOGI}

Semarang :Skripsi.

Sudiartawan, I.P. 2005.Studi Kualitas Air Sumur Gali di Desa Pengambengan Kabupaten Jembrana. (Tesis). Universitas Udayana. Denpasar

Sundra, I. K. 2006. Kualitas Air Bawah Tanah di Wilayah Pesisir Kabupaten Badung. Jurusan Biologi, Fakultas MIPA Universitas Udayana. Denpasar.

Suriawiria U. 1996. Mikrobiologi Air dan Dasar-Dasar Pengolahan buangan Secara Biologis. Alumni ITB : Bandung

Susanta, G. 2008. Panduan Lengkap Membangun rumah. Swadaya. Jakarta

Untung, O. 2004. Menjernihkan Air Kotor, Puspa Swara. Jakarta 